\title{
Genetic Modification of Animals: Potential benefits and concerns*
}

David A. Mbah ${ }^{1 *}$, Chi Lawrence Tawah $^{2}$ and Magellan Guewo-Fokeng ${ }^{3}$

${ }^{1}$ Cameroon Academy of Sciences, P.O. Box 1457, Yaoundé, Cameroon

${ }^{2}$ African Development Bank (Consultant), BP 1387, Abidjan, Cote d'Ivoire

${ }^{3}$ Post-Doctoral Intern, Cameroon Academy of Sciences, P.O. Box 1457, Yaoundé, Cameroon

*Corresponding author: David A. Mbah: dambah@yahoo.co.uk

"Science and other scholarly endeavours can and must inform public policy but the public is the ultimate decision maker about which problems are most pressing, which risks are most worth taking, and which technologies are most desirable given all the available alternatives 》

(Beth Elpern Barrows, 2002)

\begin{abstract}
Genetic modification (GM), a process whereby gene and genotype frequencies are changed among individuals of each generation, is driven by natural and artificial forces. Natural forces include mutation, fitness and migration/introgression, while artificial forces include selection, crossbreeding and transgenesis/genetic engineering. Genetic modification, driven by natural forces, is essentially adaptive, while modification driven by artificial forces is controlled by human intervention aimed at meeting food, health and other needs.

Conventional genetic modification, under sexual reproduction within species, produces both beneficial and negative effects. Modern genetic modification - interspecific exchange of genes using genetic engineering - has beneficial and negative effects as well, which are at varying degrees depending on the species involved. Control/management systems/mechanisms are developed and applied to enable societal benefits while minimizing/preventing negative effects of conventional and modern genetic modification. Targeted analysis of selected nutrients in animal products is made on a case-by-case basis to test substantial equivalence of any compositional changes resulting from genetic modification. Unique identifiers are established to track GM animals and their products in the food chain.
\end{abstract}

Received: $17 / 02 / 2020$
Accepted: $20 / 05 / 2020$
DOI: https//dx.doi.org/10.4314/jcas.v15i3.2
C The Authors. This work is licensed under the Creative Commons Attribution 4.0 International Licence.

\footnotetext{
* National Forum on the State and Challenges of Utilisation of Genetically Modified Organisms in Cameroon, $8^{\text {th }}$ to $10^{\text {th }}$ September 2015: Rapport général du forum national sur les organismes génétiquement modifies au Cameroun; www.minmidt.cm/fr/l-actualité/221-ogm-le-cammeroun-ouvre-les-debats.html?tmpl=coomponent\&print=1\&page=
} 


\section{Résumé}

Modification génétique, processus par lequel les fréquences des gènes et des génotypes sont changes parmi les individus de chaque génération, est entraînée par des forces naturelles et artificielles. Les forces naturelles incluent la mutation, compétence de mère/père pour se reproduire/survivre et la migration / introgression. Les forces artificielles comprennent la sélection, le croisement et la transgénèse / génie génétique. La modification génétique entraînée par les forces naturelles est essentiellement adaptative, tandis que celle entraînée par les forces artificielles est contrôlée par une intervention humaine visant à répondre aux besoins alimentaires, sanitaires et autres.

La modification génétique conventionnelle, lors de la reproduction sexuelle au sein des espèces, produit des effets à la fois bénéfiques et négatifs. Modification génétique moderne - échange interspécifique de gènes par génie génétique - a également des effets bénéfiques et négatifs mais à des degrés divers selon les espèces impliquées. Des systèmes / mécanismes de contrôle / gestion sont développés et appliqués pour permettre des avantages pour la société tout en minimisant / empêchant les effets négatifs des modifications génétiques conventionnelles et modernes. Une analyse ciblée de nutriments sélectionnés dans les produits d'origine animale est effectuée au cas par cas afin de tester l'équivalence substantielle de tout changement de composition résultant d'une modification génétique. Des identifiants uniques sont établis pour suivre les animaux GM et leurs produits dans la chaîne alimentaire. 


\section{Introduction}

The first forum, jointly funded by the then Ministry of Environment and Forestry (MINEF) and the Ministry of Scientific and Technical Research (MINREST), titled "Modern Biotechnology: Genetically Modified Crops, Foods and Feeds - Cameroon perspectives", was organized by the Cameroon Academy of Sciences (CAS) in 2004 (JCAS 6(1): 1 - 76) (Fig. 1). Deliberations during the Research Excellence Week (JERSIC) (MINRESI, 2009) recommended that a national biotechnology policy be developed to accompany law no. 2003/ 006 governing modern biotechnology in Cameroon. The African Science Academies at their $9^{\text {th }}$ annual meeting held in Addis Ababa, Ethiopia, in 2013 urged African governments not to let the biotechnology revolution by-pass the continent as the green revolution did (AMASA-9 Declaration). In 2014, at the request of MINRESI and with funding from the US National Academy of Sciences, CAS organized a stakeholders' forum to reflect on this recommendation. The output of the forum was entitled "Elements for a National Biotechnology Policy Framework for Cameroon” (Fig. 2).

Less than a year later, at the behest of the Ministry of Mines, Industry and Technological Development, another forum was organized to reflect further on the specific biotechnological area of genetic modification. It is expected that the results of the current forum will further inform Government policy on the rapidly changing biotechnological environment to which we need to adapt.

\section{Objective}

The objective of this report is to enable stakeholders (scientists, policymakers, developers, farmers, environmentalists) become more aware of the forces that drive changes in the genetic structure of animal populations of importance in agriculture and pharmaceuticals. It is also to enable policy/decision making on the technologies. Potential benefits and concerns will be targeted. Emphasis is paid to the following:

- Genetic modification/engineering,

- Natural and artificial forces driving genetic modification,

- Differences between conventional and modern genetic modifications,

- Intended and unintended effects/risks of genetic modification,

- Management/control of unintended effects/ risks of genetic modification.

\section{To enable understanding, the following terms are defined :}

Genome : entire genetic make up of an organism comprising all the genes and non-genes in the DNA(and RNA for viruses)

- Gene: basic hereditary unit (comprising either of DeoxyriboNucleic Acid-DNA or RiboNucleic Acid-RNA) which determines the protein structure. It is located at a point (known as locus) on a chromosome. Each member of a pair of genes at the locus is called an allele.

- Genotype: genetic identity of an individual (e.g., AA, Aa, aa where A and a represent dominant and recessive alleles, respectively).

- Phenotype: outward manifestation of genetic identity, often in interaction with the environment.

- Genetic engineering: changing genetic constitution by introduction/elimination of gene(s) using molecular biology techniques.

- Transgene: a gene construct introduced from another species into an organism by human intervention using modern genetic modification techniques.

- Genetic modification: change in gene or genotype frequencies among individuals of each generation.

- Comparator: Product that is compared to another product (e.g. GM organism/GM versus non-GM organism/GM food versus non-GM food 
- Substantial equivalence: " as safe as its conventional counterpart»

quivalence: " as safe as its conventional counterpart»

\section{Process of genetic modification}

The procedure for producing transgenic microbes (Cohen, 1975) was adapted for transgenic animals by Smith (1996). The steps include:

- Identification/construction of a foreign gene,

- Microinjection of identified DNA (gene) into pronucleus of a fertilized egg,

- Implantation of resulting recombinant (chimera) egg (cells) into surrogate mothers,

- Development of embryo to term,

- Proving that the foreign DNA has been stably and heritably incorporated into the DNA of at lease some of the newborn offspring, and
- Demonstrating that the gene expresses itself in the new environment (recombinant).

Using this procedure: rat gene (for growth hormone) was inserted into a mouse genome.

It expressed itself producing progeny that were much larger than parents (Nicholl, 1994) $=>$ first Transgenic animals

Since then, transgenic cows, sheep, goats, pigs, rabbits, chickens, and fish have been produced (Table 1). Transgenic cows expressing desirable trait for milk protein composition and quality have been cloned (Brophy et al, 2003). Incidentally, cloning does not introduce significant differences between bovine clones and their genetic and breed comparators in meat and milk production and composition (Tian et al, 2005; Laible et al, 2007).

Table 1: State of transgenic technology in animal production*

\begin{tabular}{lllccr} 
Organism & Transfection & \multicolumn{2}{c}{ Viral Vectors } & Transposon & Embryonic stem cells \\
Mouse & $4+$ & 2 & 1 & $4+$ & 2 \\
Cow & 3 & 1 & - & - & 2 \\
Sheep & 3 & - & - & - & 2 \\
Goat & 3 & - & - & - & 2 \\
Pig & 3 & - & - & - & 2 \\
Rabbit & 3 & - & - & - & - \\
Chicken & 1 & 2 & - & - & - \\
Salmon (Atlantic) & 3 & - & - & - & - \\
Catfish & 2 & - & - & - & - \\
Tilapia & 3 & - & - & - & - \\
Zebrafish & 1 & - & - & - & - \\
Crustaceans & 1 & 1 & - & -
\end{tabular}

*Adapted from NRC, 2002; (Mbah, 2006)

$1=$ proof of concept, $2=$ routine experimental use, $3=$ commercialization sought, $4=$ widespread production $(+=$ experimental use)

The genetic engineering just treated has undergone a second generation of technologies classified as genome/gene editing (NIH, 2020). Briefly, it involves a 'group of technologies' used by scientists to change the DNA of an organism. They may be used to introduce, remove or alter locations in the genome. The most recent of these technologies CRISPR - Cas9 ('clustered regularly interpaced short palindromic repeats CRISPR and CRISPR - associated protein 9) is the most efficient, accurate and faster than others. The operation of the system involves the following steps:

- scientist creates a piece of RNA with guiding sequence that binds to target DNA in a given genome

. the RNA binds to Cas9 enzyme as well, giving rise to modified RNA, - modified RNA recognizes the DNA sequence, . Cas9 enzyme cuts the DNA at targeted position, and 
. using the cell's DNA repair system, scientist introduces 'customized' DNA to add, delete or change DNA sequence of the genome.

This technology may be important in public health(sickle cell, hemophilia, cystic fibrosis, cancer, heart disease, mental health and HIV infection). When the gene- editing is in germ cells, it can be passed to the following generation. Given ethical considerations, the use of the technology is still under study.

Recent reports on genome/gene editing for animal improvement include Michel et al,2019; Van Eennennaam, 2017; Van Eennenaam et al, 2019; Van Eennenaam,2019; Shakil et al, 2017. The regulatory status of animals submitted to genome/gene editing is not settled (Van Eennenaam et al, 2019).

Genetic modification involves normal/random or disturbed/directed situation (forces acting on normal/random situation).

\section{Normal/Random Situation :}

- Genetic structure of population of animals is determined by proportions of different genotypes in the population (Falconer, 1996) (e.g. for locus « $\mathrm{A}$ », the number of $\mathrm{AA}, \mathrm{Aa}$, aa individuals in a population of 100 ?);

- Proportions in current generation determine proportions in next generation;

- For locus A in entire population, assume :

- frequency of $\mathrm{A}=\mathrm{p}$

- frequency of $\mathrm{a}=\mathrm{q}$

$-p+q=1$

and that for next generation, gametes produced are:

$\mathrm{AA}=>$ A gametes ( 1 type)

$\mathrm{Aa}=>\mathrm{A}$ and a gametes (2 types)

aa $=>$ a gametes $(1$ type $)$

The result at a single locus (A) is expressed by the following ratio:

$\mathrm{p}^{2}(\mathrm{AA}): 2 \mathrm{pq}(\mathrm{Aa}): \mathrm{q}^{2}(\mathrm{aa})$
- When: 1. p \& q remain unchanged, and

2. There is random mating

Disturbed/Random Situation: forces acting on normal/random situation

1. Natural forces:

1.1 Mutation: heritable change in gametes from one allele to another

$$
\begin{gathered}
\mathrm{U} \\
\mathrm{A} \Leftrightarrow \mathrm{a}
\end{gathered}
$$

$\mathrm{V}$

Where $\mathrm{U}$ and $\mathrm{V}$ are mutation rates:

If $\mathrm{U}=\mathrm{V}$, mutation has no effect.

If $\mathrm{U}^{\text {" }} \mathrm{V}$, mutation is directional and effective. Hence, $\mathrm{p}$ and $\mathrm{q}$ may be modified (increased or decreased).

- The genetic structure of the next generation will depend not only on the gene frequencies in the preceding generation but also on the mutation rate.

1.2. Survival forces

* Fitness

- some alleles affect the ability to survive to reproductive age:

- some alleles affect ability to produce viable offspring, while

- some genotypes die early or are handicapped in one way or another relative to mating chances.

The result is «fitter » individuals (genotypes) determine the genotypes and gene frequency for the next generation. Such a generation has fewer or no "defective " genes. It is therefore genetically different from the preceding generation.

\section{Disturbed/Directed Situation}

2.1. Migration (Introgression)

A population of animals may be composed of « natives » and « immigrants ». The « immigrants » may modify the genetic structure of the population by increasing a given gene frequency. For given locus (Falconer and Mackay, 1996): $\mathrm{q}=$ gene frequency among natives, $\mathrm{q}^{\circ}=$ gene frequency among immigrants, $\mathrm{q}_{1}^{\mathrm{m}}=$ gene frequency among mixed population, 
$\mathrm{q}_{1}=\mathrm{mq}_{\mathrm{m}}+(1-\mathrm{m}) \mathrm{q}_{\mathrm{o}}=\mathrm{m}\left(\mathrm{q}_{\mathrm{m}}-\mathrm{q}_{\mathrm{o}}\right)+\mathrm{q}_{\mathrm{o}}$

Where: $\mathrm{m}=$ proportion of new immigrants/ generation

Change in gene frequency in mixed population due to one generation of immigrants:

" $\mathrm{q}=\mathrm{q}-\mathrm{q}$ $={ }^{1} \mathrm{~m}\left(\mathrm{q}_{\mathrm{m}}^{\mathrm{m}}-\mathrm{q}_{0}\right)^{\mathrm{o}}$

Thus, the rate of change in gene frequency in a population undergoing immigration (introgression) depends on:

a) immigration rate $(\mathrm{m})$, and

b) difference in gene frequency between « immigrants $\left(\mathrm{q}_{\mathrm{m}}\right)$ and

« natives $»\left(\mathrm{q}_{0}\right)$.

2.1. Animal breeding $=>$ Sexual reproduction

(a) selection is based on the defined criteria to determine individuals for mating to produce individuals with given traits (productivity, quality, resistance to physical and biotic stresses) in the next generation.

(b) Crossbreeding combines lines, varieties, breeds or species characteristics/differences in chosen traits (productivity, quality, resistance to physical and biotic stresses) for desired results.

Note that $(\mathrm{a})+(\mathrm{b})$ techniques are based on the « breeding value » (i.e. value associated with genes carried by individuals and transmitted to their progeny/offspring.
The measure of breeding values is the "average effect» (Falconer and Mackay, 1996).

The average effect may be assigned to:

(a) a gene in the population, or

(b) the difference between one gene and another of an allelic pair.

The « average effect of a gene » then is the " mean deviation from the population mean of individuals which received the gene from one parent, the gene from the other parent having come randomly from the population » (e.g. 20 calves receiving a gene A, from 1 bull mating 40 cows which donate the other allele, a).

This is easier seen as the "average effect of a gene substitution » at one locus of 2 alleles (e.g. changing « $\mathrm{A}$ » to "a" (i.e. Aa $->$ aa) in a population. The average effect of gene substitution depends on the gene and the population. It is high when gene frequency is high and low when gene frequency is low.

Results from IRAD Wakwa Centre (Fig. 3) show how during a 17 year period selection (conventional genetic modification) modified the genetic structure of Gudali beef cattle population (Ebangi et al, 2002) with long generation intervals (7-8 years) (Tawah et al, 1994). The target trait was growth (increased beef production).

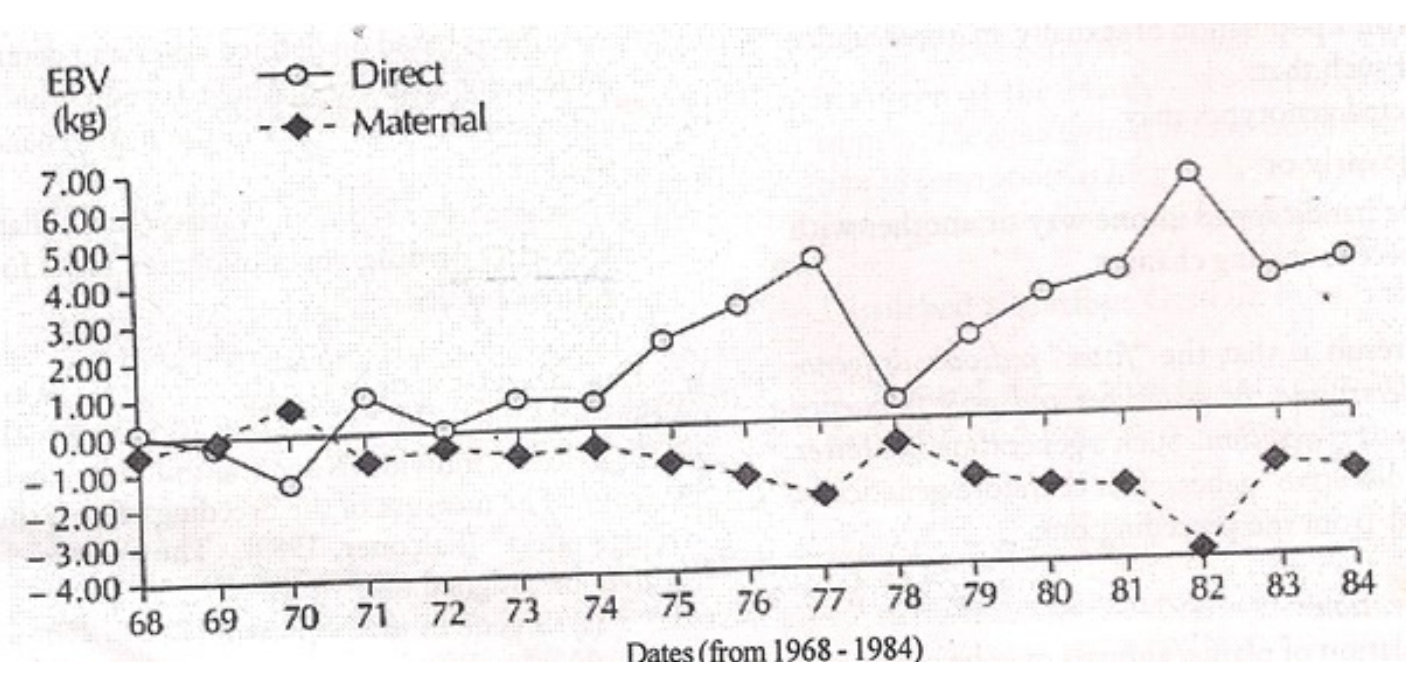

Fig 3. Direct and maternal genetic trends for yearling weight in Gudali beef Cattle. EBV = estimated breeding value 
Comment: Total Direct Gain: +5.5 kg EBV

Total Maternal Gain: $-2.5 \mathrm{~kg}$ EBV

Total Genetic Trend: + $3.0 \mathrm{~kg}$ EBV

(resulting from negative genetic correlation of $0.81)$

Many genes are involved.

2.2. Crossbreeding (Fig. 4a, b, c and d) by the Tadu Dairy Cooperative Society (TDCS)): Meat and milk - many genes are involved.

You easily note phenotype differences/looks. At genetic/breeding level, their productivity is far better than the unimproved local breed (Tawah et al, 1996; Tawah et al, 1998) in production traits.

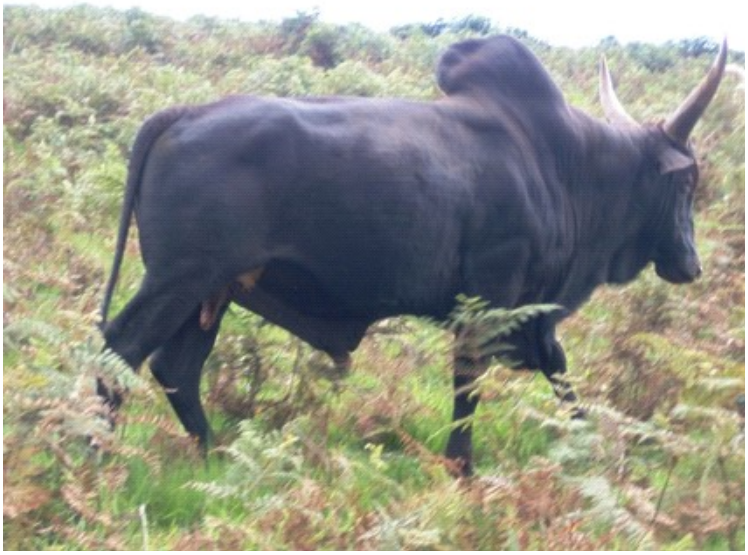

4a: Gudali bull (TDCS)

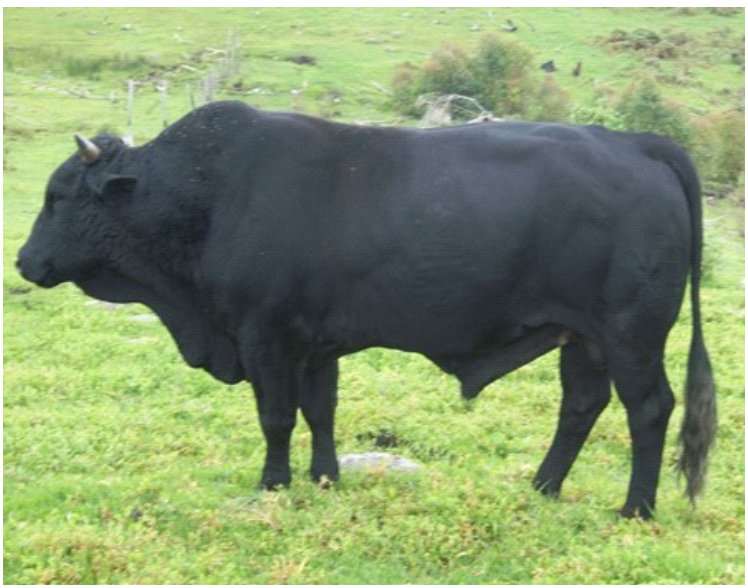

4b: Holstein (67.5\%)-Gudali (32.5\%) bull (TDCS)

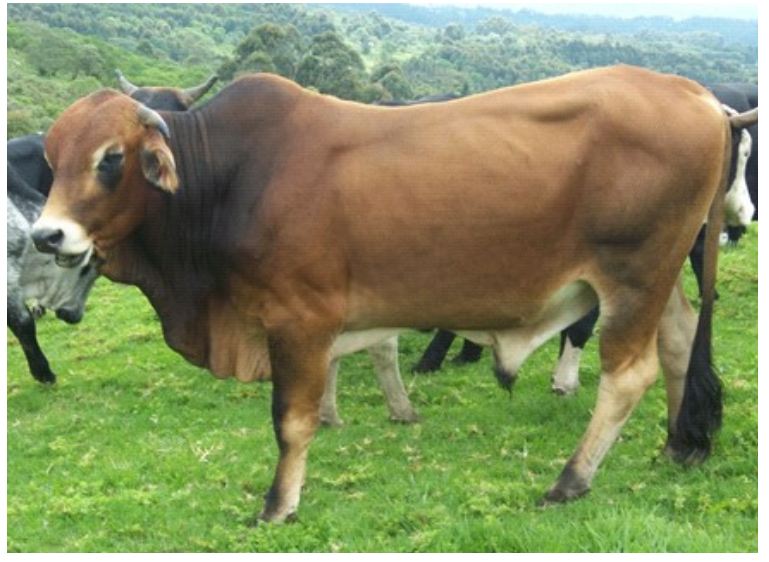

4c: Brahman (50\%)-Gudali (50\%) bull (TDCS)

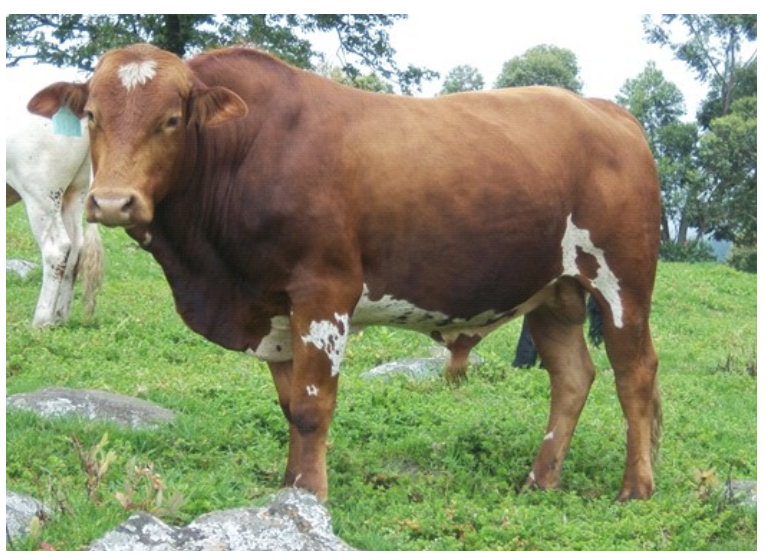

4d: Simmental (50\%)-Gudali (50\%) bull (TDCS)

\subsection{Genetically engineered animals}

2.3.1. Animals are also genetically modified to satisfy pharmaceutical and other needs. Table 2 shows genetic modification of animals for pharmaceutical products. 
Table 2. Transgenic Animals: Potential Producers of Pharmaceuticals

\begin{tabular}{|c|c|}
\hline Species & Pharmaceutical Product \\
\hline Chicken & $\begin{array}{l}\text { - Monoclonal antibodies } \\
\text { - Lysozyme } \\
\text { - Growth hormone } \\
\text { - Insulin } \\
\text { - Human Serum albumin }\end{array}$ \\
\hline Rabbit & $\begin{array}{ll}\text { - } & \text { Calcitonin } \\
\text { - } & \text { Superoxide dismutase } \\
\text { - } & \text { Erythropoietin } \\
\text { - } & \text { Growth hormone } \\
\text { - } & \text { IL-2 } \\
\text { - } & \text { X-glucosidase } \\
\end{array}$ \\
\hline Goat & $\begin{array}{ll}\text { - } & \text { Antithrombin III } \\
\text { - } & \text { Tissue plasminogen activator } \\
\text { - } & \text { Monoclonal antibodies } \\
\text { - } & \text { X-1-Antitrypsin } \\
\text { - } & \text { Growth hormone } \\
\end{array}$ \\
\hline Sheep & $\begin{array}{ll}\text { - } & \mathrm{x}-1-\text { Antitrypsin } \\
\text { - } & \text { Factor VIII } \\
\text { - } & \text { Factor IX } \\
\text { - } & \text { Fibrinogen } \\
\end{array}$ \\
\hline Cow & $\begin{array}{ll}\text { - } & \text { Human serum albumin } \\
\text { - } & \text { Lactoferrin } \\
\text { - } & \text { x- Lactalbumin } \\
\end{array}$ \\
\hline
\end{tabular}

Source: NAS (2002), van Berkel et al(2007)

\subsubsection{Genetically engineered animals for food}

Table 1 above presents the situation. While Baily (2019) concludes that « moving away from animal research including the use of GM animals has never been more imperative ", he does not recommend an alternative. The EFSA GMO Panel (2013) has, however, produced rigorous guidelines for the environmental risk assessment of genetically modified animals.

Some of the animal production problems that need only modern genetic modification techniques (CAS, 2014; Vermaak et al, 2015; The Roslin Institute, 2015) to resolve include:

- African Swine Fever (Pigs),

- Foot and Mouth Disease (Cattle),

- Trypanosomiasis (Cattle),

- Coccidiosis (Chickens),

- Bird Flu (Chickens), and

- African Horse Sickness (Horses).
These are livestock production problems that conventional genetic modification techniques are unable to address.

\section{Unintended effects of selection/ crossbreeding:}

Success in a selected trait may lead to undesirable consequences:

* negative genetic correlation as in the EBV above, $*$ increased size resulting in increased pressure on the environment,

$*$ increase in fitness (reproductive) resulting in need for more space and pressure on the environment and other species,

* genetic erosion (particularly if replaced genotypes, varieties, races, breeds, species are not conserved).

Management/Handling of Unintended Effects of selection/crossbreeding

- involving more than one trait in selection,

- determining carrying capacities for given pasture lands, etc.,

- off-take rate to allow " ecologically sound » stocking rate,

- conservation (in situ and/or ex situ) of displaced genes (breeds)

\section{Transgenesis/Genetic Engineering}

Transgene (tg) (Braig and Yan, 2002):

$\mathrm{q}_{\mathrm{tg}}=\frac{\mathrm{n}_{\mathrm{tg}}}{2 \mathrm{~N}} ;$ e.g. $\frac{100}{2(1000)}=\frac{1}{20}=0.05$

Where $\mathrm{n}=100=$ number of alleles of $\operatorname{tg}$ in the population

$\mathrm{N}=1000=$ population size of the diploid population

If q increases, transgenic individuals (GMOs) have tg advantage over their wild types.

The transgene may:

1. Introduce a novel/new trait in the population where the trait did not exist (i.e. $q=0$ ) 
2. Increase the intensity (where trait exists i.e. $\left.\mathrm{q}_{\mathrm{tg}}>0\right)$

$20 \mathrm{q}=\mathrm{q}_{\mathrm{tg} 1}-\mathrm{q}_{\mathrm{tg} 0}$

Where $\mathrm{q}_{\mathrm{tgo}}>0$ in the population,

When the initial $\mathrm{q}_{\mathrm{tg}}$ is «above the critical threshold» density, the transgene can be spread and fixed within 60-100 generations.

How many genes are involved?
Environmental effects: Transgenic animal entering the environment through release or escape.

Transgene could spread through:

* vertical transmission (reproduction with wild relatives), and

* horizontal transmission by vectors.

Some risk factors associated with genetically modified animals are shown in Table 3 below.

Table 3: Risk factors for genetically modified animals*

\begin{tabular}{|c|c|c|c|c|c|}
\hline Animal & $\begin{array}{c}\text { Capacity to } \\
\text { become untamed }\end{array}$ & $\begin{array}{l}\text { Possibility of escape } \\
\text { from captivity }\end{array}$ & Mobility & $\begin{array}{l}\text { Community } \\
\text { Disruptions }\end{array}$ & Level of risk \\
\hline Fish & $\mathrm{H}$ & $\mathrm{H}$ & $\mathrm{H}$ & $\mathrm{Ma}$ & $\mathrm{H}$ \\
\hline Mice \& rats & $\mathrm{H}$ & $\mathrm{H}$ & $\mathrm{H}$ & $\mathrm{Ma}$ & \\
\hline Cat & $\mathrm{H}$ & $\mathrm{H}$ & Mo & $\mathrm{Ma}$ & \\
\hline Pig & $\mathrm{H}$ & Mo & $\mathrm{L}$ & $\mathrm{Ma}$ & \\
\hline Goat & $\mathrm{H}$ & Mo & Mo & S & \\
\hline horse & $\mathrm{H}$ & Mo & $\mathrm{H}$ & F & \\
\hline Rabbit & $\mathrm{H}$ & Mo & Mo & $\mathrm{F}$ & \\
\hline Mink & II & II & Mo & - & \\
\hline Dog & Mo & Mo & Mo & $\mathrm{F}$ & \\
\hline Chicken & $\mathrm{L}$ & Mo & Mo & - & \\
\hline Sheep & $\mathrm{L}$ & $\mathrm{L}$ & $\mathrm{L}$ & $\mathrm{F}$ & \\
\hline Cattle & $\mathrm{L}$ & $\mathrm{L}$ & $\mathrm{L}$ & - & $\mathrm{L}$ \\
\hline
\end{tabular}

*Adapted from NRC, 2002; (Mbah, 2006)

$\mathrm{H}=$ high, $\mathrm{Ma}=\mathrm{Many}, \mathrm{Mo}=$ Moderate, $\mathrm{F}=$ few, $\mathrm{S}=$ some, - none,

reducing risk

Food safety (products from beef/dairy, cattle, sheep/goats, poultry and eggs, pigs, rabbits, fish, etc.): New/introduced genes could lead to new proteins which may have the following effects:

* allergenicity,

* bioactivity (of molecules enhancing growth, etc), and

* toxicity

Animal health: Ruminants (cattle, sheep, goats) produced through somatic nuclear transfer (SCNT) methods containing transgenes (or not) could lead to:

* higher birth weights,

* longer generation lengths than for calves/lambs from artificial insemination.
Comment: Efficiency of methods: Extremely inefficient $(0-4 \%$ in cattle, sheep, goats, pigs).

* Mortality: 80-90\% during early development,

* Many survivors show improper expression of inserted gene,

* Many survivors show abnormalities: anatomical, physiological, behavioral.

\section{Management/Control of the Risks} (Cameroon National Biosafety Committee, 2004: 30-31)

1. Risk assessment: Case by case as follows:

* Concern about genetically modified organisms’ (GMO) activity identified,

* Potential harm evaluated, 
* Likelihood and consequence of harm determined,

* Risk management procedure(s) investigated,

* Acceptance of the risk evaluated,

* Activity is either:

a) approved with or without risk management, or

b) refused until more information is available.

\section{Risk Management:}

* differs from animal to animal and gene to gene,

* focuses on containing the GM animal and novel gene(s) within the activity area, minimizing accidental release, and ensuring removal of the GM animal from the environment after testing,

* applicant proposes risk management methods (to minimize likelihood of real harm),

* biosafety review team assesses the proposed measures,

* biosafety review team approves the measures or recommends modification,

* regulators append recommended GM measures as conditions for authorization.

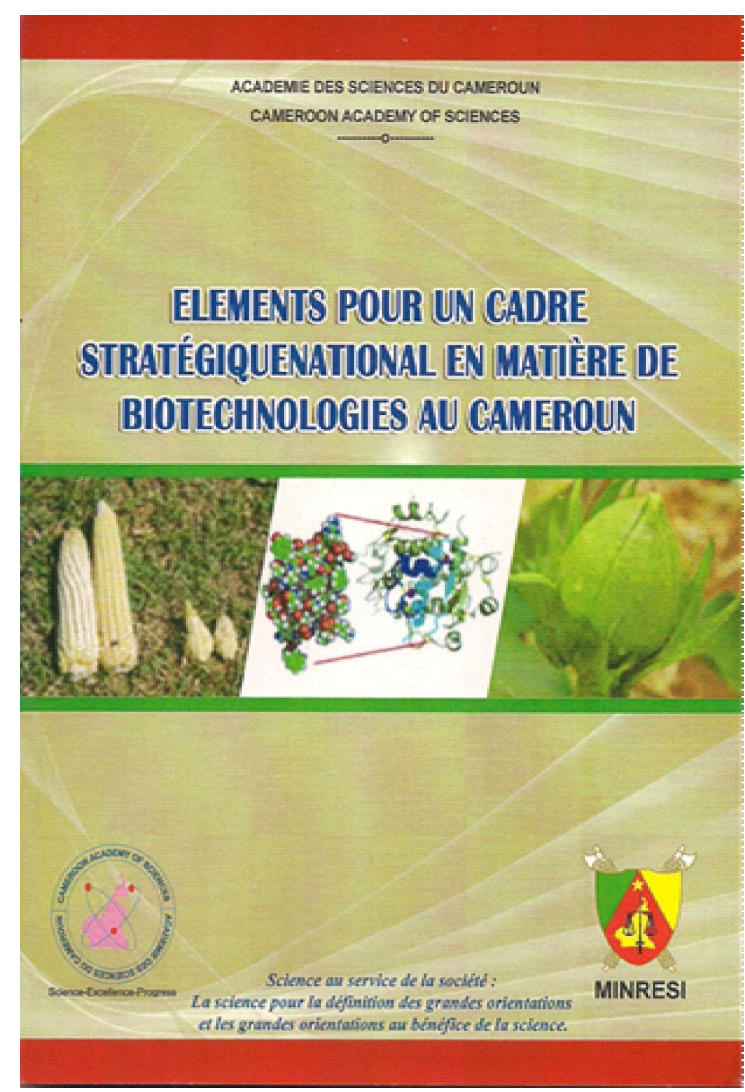

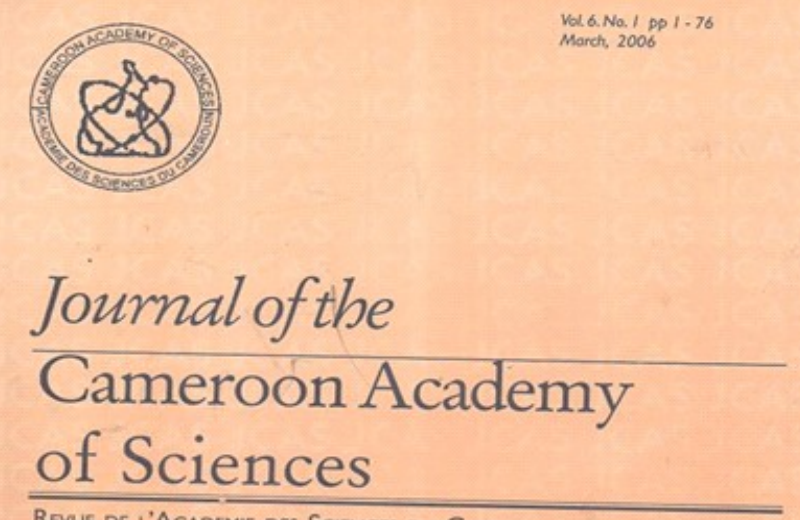

Revue de l'Academie des Sciences du Cameroun

Modern Biotechnology: Genetically Modified Crops, Foods and Feeds: Cameroon Perspectives

Proceedings of a Symposium organized by the Cameroon Academy of Sciences in Yaounde on July $23-24,2004$

CAMEROON ACADEMY OF SCIENCES $158 N 9956-26-053-3$

Fig 1.

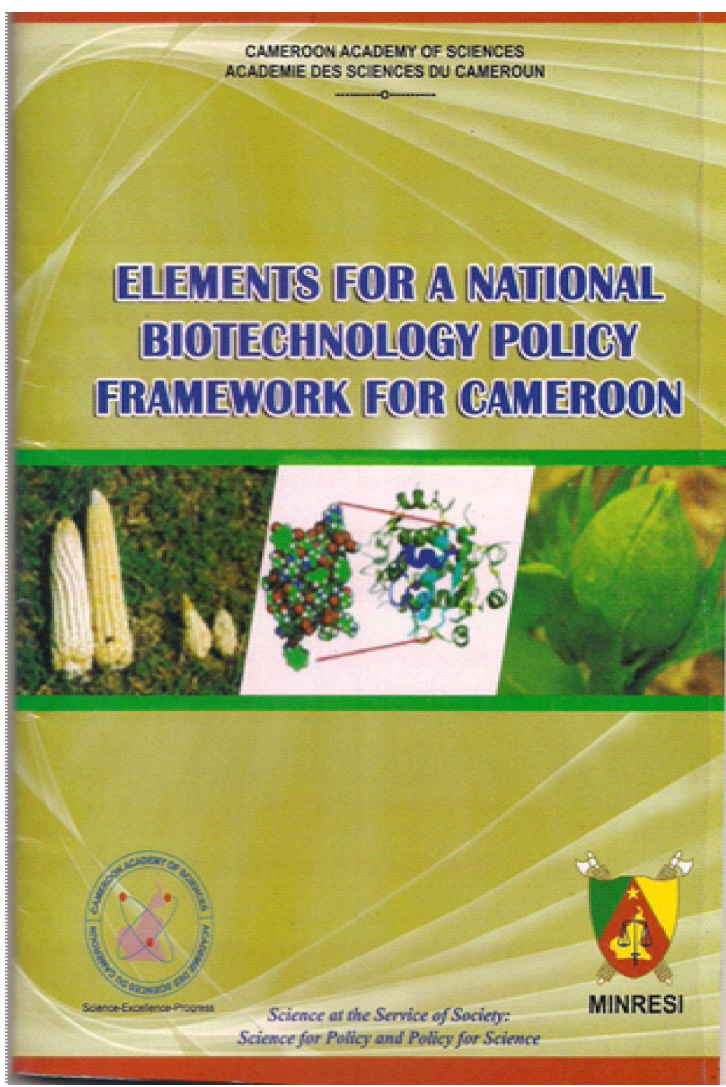

Fig 2. 


\section{Conclusion}

Presentation of all forces that drive modification/ change of the genetic structure of a population of animals has been made. The forces are natural and artificial. Man manipulates the forces for food and health needs. Negative effects/unintended effects of such manipulation are controlled/ regulated. The result is use of genetically engineered animals and their products are subjected to risk analyses, and biosafety regulation aimed at adoption for use of beneficial effects while eliminating/managing negative effects. Adoption or no adoption of technology is on a case by case basis.

\section{References.}

Bailey J. 2019. Genetic Modification of Animals: Scientific and Ethical Issues. In: K. Henmann, K. Jayne(eds): Animal Experimentation: Towards a Paradigm Change: Vol. 22,pp.711 DOI:10.1163/9789004391192_020.

Barrows B.E. (eds): Genetically Engineered Organisms: Assessing Environmental and human health effects. CRC Press, Washington, D.C. pp 251-314

Beth Elpern Barrows. 2002. In: D.K. Letoumeau, Beth Elpern Barrows (Eds): Genetically Engineered Organisms: Assessing Environmental and Human Effects.

Braig H.R. and Yan G. 2002. The spread of genetic constructs in natural insect populations. In: Le Tourneau D.K.,

Brophy B., Smolenski, Wheeler T., Wells D., L'huillier, P., Laide G. 2003. Cloned transgeneic cattle produce milk with higher levels of B-casein and K-casein Nat. Biotechnology 21: 157-162 CAS. 2014. Elements for national biotechnology policy framework in Cameroon. Cameroon Academy of Sciences. www.casciences.com
Cohen S.N. 1975. The Manipulation of genes. In: Freifelder D. (Ed.): Recombinant DNA, Scientific American, Freeman. Pp. 113-121

Ebangi L.A., Erasmus G.J., Tawah C L., Mbah D.A. 2002. Genetic trends for growth in a selection experiment involving purebred and twobreed synthetic beef breed in a tropical environment. Rev. Elev. Med. Vet. Pays trop. 55 (4) $305-212$

EFSA GMO Panel (EFSA GMO Panel on Genetically Modified Organisms), 2013. Guidance on the environmental risk assessment of genetically modified animals. EFSA Journal 2013 ; 11(5): $\quad 3200, \quad 190 \quad$ Pp doi :10.2903/ j.efsa. 2013.3200

Falconer D.S., Mackay F.C. 1996. Quantitative Genetics (23-36). Pearson/Preatice Hall

Götz Laible*, Brigid Brophy, Derek Knighton, David N. Wells (2007) Compositional analysis of dairy products derived from clones and cloned transgenic cattle: pp. 166-167

Mbah D.A. 2006. Genetic Modification: natural selection, artificial selection and genetic engineering. JCAS 6(1): 19-24.

Mbah D.A. 2006. Biotechnology and Animal Production. JCAS 6(1): 29-40.

Michel G., Carole C., Hayes B. 2017. Harnessing genomic information for livestock improvement. Nature Reviews Genetics 20 : 135 - 156. Https:/ /www.nature. Com/articles/s41576-018-0082-2 National Academy of Sciences (NAS) 2002. Animal Biotechnology; Science-based concerns. Pp. 181. The National Academies Press, Washington, D.C. 
National Academy of Sciences (NAS) 2004. Safety of Genetically Engineered Food: Approaches to assessing unintended health effects. Pp.235

NIH. 2020. What are genome editing and CRISPR - Cas9 ? https ;//ghr.nlm.nih.gov/primer/ genomicresearch/genomeediting

Patrick H.C. van Berkel ${ }^{1 *}$, Mick M. Welling ${ }^{2}$, Marlieke Geerts1, Harry A. van Veen1, Bep Ravensbergen $^{3}$, Mourad Salaheddine ${ }^{1}$, Ernest K.J. Pauwels ${ }^{2}$, Frank Pieper1, Jan H. Nuijens1, and Peter H. Nibbering ${ }^{3}$ : 2002. Large scale production of recombinant human lactoferrin in the milk of transgenic cows, Nature biotechnology, vol. 20 pp. $484-487$

Pingpoh D. P., Mbah D. A., Tawah C. L. 2019. Profitability of Agricultural Research: The Case of Genetic Improvement Cattle for Milk Production in Cameroon. JCAS 15(1): 3 - 8

Shakil A.B., Abrar A. M.; Syed M. A. ; Riaz A. S., Nazir A. G. , Syed S. S., Nadeem S. 2017. Advances in genome editing for improved animal breeding. Vet. World 10(11): 1361 - 1366

Tawah C. L., J. O. E. Rege, D. A. Mbah, H. Oumate. 1994. Genetic evaluation of growth performance of purebred and two-breed synthetic beef cattle population under selection in Cameroon.: Genetic and phenotypic trends. Anim. Prod. 58: 25-34

Tawah C. L., D. A. Mbah, Ph. Lhoste. 1996. Ffects of Bos Taurus genes on pre-weaning growth of zebu cattle on the Adamawa highlands, Cameroon. Tropical Agriculture(Trinidad): 73(4): $314-319$

Tawah C. L,; D. A. Mbah, O. messine, M. B. Enoh. 1998. Effects of Gentype and Environment on
Milk Production and Reproduction of Improved Gentypes from the Tropical Highlands of Cameroon. $6^{\text {th }}$ World Conference on Genetics Applied to Livestock Production, Armidale, Australia: 205 - 208

Tian X. C, C. Kubota, K. Sakadicta X. Yang. 2005. Meat and milk compositions of bovine clones. PNAS. 102 (18): 6261-6266

The Roslin Institute. 2015. GM Chickens that Don't transmit Bird Flu. http:// www.roslin.ed.ac.uk/public-interest/gm-chickens. Accessed 12/8/2015

Van Eenennaam A. L. 2019. Application of genome editing in farm animals: Cattle. Transgenic Research 28: $93-100$

Van Eenennaam A. L., Wells K. D., Murray J. D. 2019. Proposed U. S. regulation of gene-edited food animals is not fir for purpose. Nip Science of Food: 3. Article number 3. https:// www.nature.com/articles/s41538-019-0035-1

Vermaak E., Paterson D. J., Conradie A., Theron J. 2015. Directed Genetic Modification of African Horse Sickness Virus by Reverse Genetics. SAJS 111(7/8): $1-8$

\section{Other References (attention: Scientists, Regulators)}

Hilbeck A. and Andow D. A. (eds). 2004. Environmental Risk Assessment of Genetically Modified Organismes Vol. 1: A case study of Bt maize in Kenya. CABI Publishing. Pp. 281

Hilbeck A. Andow D.A. and Fontes ENG. 2006. Environmental Risk Assessment of Genetically ModiGfied Organisms. Vol. 2: Methodologies for assessing BT cotton in Brazil. CABI Publishing. 